\title{
社会資本構造物及び建築物防食の歴史的発展 *
}

\author{
松島巖** \\ ** 前橋工科大学
}

\section{Corrosion Engineering of Social Infrastructures and Buildings}

-A Historical Review of Events of Past Half Century -

\author{
I wao Matsushima** \\ ** M aebashi Institute of Technology
}

\begin{abstract}
Development of corrosion engineering of social infrastructures and buildings in the past half century has been reviewed in connection with the changes and resulting requirements of society. It was intended to pass down the historical background of the present technology to the new generation. Following a brief historical review, an account of ten important topics was given in more details. Included are the use of unpainted weathering steel, cathodic protection of buried pipelines in the early days, quality control of concrete to avoid corrosion of steel reinforcements, mitigation against delayed failure of high-strength bolts for structural bolting, development of groovecorrosion resistant welded water pipe, prevention of premature corrosion of buried utility piping, application of heavy-duty paint coating systems for long-span bridges over straits, various linings for splash-zone protection, instructive impact by a book " America in Ruins" authored by P.Choate and S.Walter, and use of rust-proof stainless steel and titanium for exterior of buildings for amenity.
\end{abstract}

Key words : social infrastructure, weathering steel, cathodic protection, pipeline, reinforced concrete structure, high-strength bolts, buried utility piping, heavy-duty coating system, lining for splash-zone

1. 緒言

本稿は，1960 年頃から現在に至る社会資本構造物及び 产の他の鋼構造物防食の, 歴史的発展を述べたものであ る***.この間防食法は大いに進歩したが，弚の歴史的 背景を述べ，次世代の関係技術者の参考に供することを 目的としている.

当然, 正史を骨子としているが，関係者のみに知られ ている事実や，当事者としての筆者が教訓的であると考 える事項を加えた .これらは重要であるにもかかわらず 他の文献にはあまり記述されていないからである .

第 2 章でこの期における社会の動きとこれに対応する 防食技術の概要を述べ, 第 3 章ではこれらの中から，鋼 構造物防食に関するトピックスを取り上げてやや詳しく 扱う. 技術の具体的内容や関連データについては，第 3 章に付した参考文献を参照されたい．

\section{2. 社会の動きと防食技術}

1960 年代から現在に至る, 防食に直接, 間接かかわっ た社会の動きと，これらに呼応した腐食防食の世界にお ける出来事を，10年を区分として表 1 に示した .

1960 年代は 1950 年代後半から始まった高度経済成長 が維持発展した年代であり, 東海道新幹線や首都高速道 路が完成し, 東京オリンピックが開催された . 大型の社 会資本構造物や关の他の構造物の建設を合理化するため のニーズから高張力鋼や耐候性鋼が開発されたが, 前者

関東支部技術交流会 (東京, 2006 年 1 月 20 日) で講演

** T 371-0816 前橋市上佐鳥町 460-1 (460-1 Kamisadori-machi, M aebashi, 371-0816 Japan)
では化学装置での腐食割れ，後者ではさび層安定化不良 のケースが問題となった .一方, 鉄筋コンクリート構造 物の建設ラッシュから細骨材である川砂が不足した結果 海砂の使用が増加し，付着塩分の洗浄除去不良による鉄 筋の腐食の問題が生じた．また，工事現場ではなく工場 で第三者の手で調配合されるフレッシュコンクリート (生コン) の使用が一般化し ,品質管理が十分行き届かず， 粗悪なコンクリート構造物が蓄積されて行った .この 「付け」は 80 年代以降に支払うことになる .

1970 年代には, 高度経済成長の副産物である大気污染 の対策が本格化した .このため, 工場一般の排煙脱硫装 置, 石油精製工場の重油脱硫装置などの材料選定や防食 法の研究が進められた . 1974 年 9 月, 米国のドレスデン 2 号炉と呼ばれる沸騰水型発電用原子炉 (BWR) の高温 水再循環系バイパスラインに使われていた type 304 配管 の溶接部付近に生じた割れが応力腐食割れとされ, 調査 の結果，世界中で同樣な割れが発見された .これは本稿 の対象ではないが，膨大な人手と費用をかけた長期にわ たる研究活動の対象となった .

1973 年に到来した第一次石油危機の結果, 高度経済成 長時代は終わりを告げ, 腐食損傷に関連する経費節減を 図るため, 工場などで装置の防食管理が強化された .こ れに関連して，腐食モニタリング，統計的手法による寿 命予測などの研究や実用が盛んとなった。

1980 年代, 低経済成長化の影響が，腐食防食の世界で も顕著となった．高度経済成長時代に多数建設された橋 梁のメンテナンスのための塗装の費用が経済を圧迫する ようになり，耐候性鋼の無塗装使用が始まり，拡大して 行った，一方，本州四国連絡橋の建設が始まり，長期の

*** 視点の異なる歴史的推移を記述したものに, 本筆者による他の文 献 1),2) がある 
表 1 社会の動きと腐食防食の世界

\begin{tabular}{|c|c|c|}
\hline 西暦 & 社会の動き & 腐食防食の世界 \\
\hline $\begin{array}{l}1960 \\
\text { 年代 }\end{array}$ & $\begin{array}{l}\text { 高度経済成長 } \\
\text { 社会資本整備（新幹線・高速道路） } \\
\text { 川砂枯渴 } \\
\text { 大気污染 } \\
\text { 長距離パイプライン時代へ } \\
\text { 超高層のあけぼの } \\
\end{array}$ & 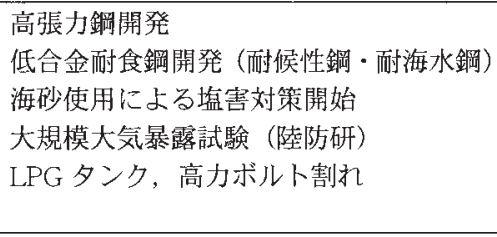 \\
\hline $\begin{array}{l}1970 \\
\text { 年代 }\end{array}$ & $\begin{array}{l}\text { 大気污染対策 } \\
\text { 石油ショック ('73) } \\
\text { 原子炉配管の割れ }\end{array}$ & $\begin{array}{l}\text { 公害防止機器腐食対策 } \\
\text { BWR 配管応力腐食割狆研究 } \\
\text { 耐みぞ状腐食電縫鋼管研究開発 } \\
\text { 腐食コストの調査 ('74) } \\
\text { 防食管理の強化 (モニター・統計的手法) }\end{array}$ \\
\hline $\begin{array}{l}1980 \\
\text { 年代 }\end{array}$ & $\begin{array}{l}\text { 低経斎成長 } \\
\text { 長大橋時代へ(本四橋建設開始) } \\
\text { 「荒廃するアメリ力」 } \\
\text { 安全・長寿命化（自動車・埋設管· } \\
\text { 橋梁) } \\
\text { 港湾施設劣化 } \\
\text { 構造物美麗化 }\end{array}$ & 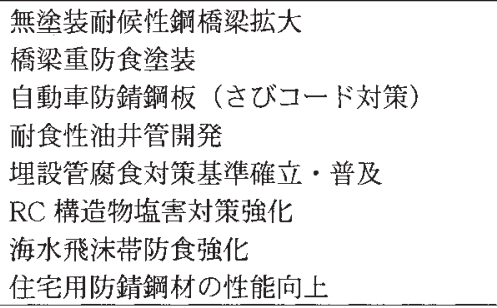 \\
\hline $\begin{array}{l}1990 \\
\text { 年代 }\end{array}$ & $\begin{array}{l}\text { 地球環境保全・省エネルギー } \\
\text { 酸性雨問題化 } \\
\text { 海洋污染防止強化 } \\
\text { 森林保護強化（米国） } \\
\text { 阪神淡路大震災 ('95) }\end{array}$ & $\begin{array}{l}\text { 新エネルギー用耐食材料研究開発 } \\
\text { 文化財の腐食対策（酸性雨） } \\
\text { 二重船体タンカーの叙装合理化 } \\
\text { スチールハウスの耐食性 } \\
\text { 腐食コスト調査（'97） } \\
\text { 「コンクリートが危ない」 }\end{array}$ \\
\hline $\begin{array}{l}2000 \\
\text { 年代 }\end{array}$ & $\begin{array}{l}\text { グローバル化 } \\
\text { 循環型社会構築 } \\
\text { 高度情報通信社会構築 } \\
\text { ナノ・バイオ研究開発 } \\
\text { 高龄化社会進展 } \\
\text { 多様化の時代 } \\
\end{array}$ & $\begin{array}{l}\text { メンテナンスの省力化 } \\
\text { 海上空港建設（含 : 鋼製栈橋構造） } \\
\text { 腐食防食研究の多様化 } \\
\text { 超高力ボルト開発 } \\
\text { 埋設管の交流腐食対策 }\end{array}$ \\
\hline
\end{tabular}

1990 年代は, 地球環境保全・省工 ネルギーガクローズアップした年代 である.燃料電池の開発, 地熱発電 の拡大，ごみ処理発電の効率化など クリーンエネルギー開発上のニーズ から, 腐食が問題となる構成材料が 研究開発された . 原油タンカーの事 故に伴う海洋污染の対策としてタン カーの二重船体化が義務づけられる ようになり，防食塗装面積の拡大か ら, 塗装作業の合理化と高品質化が 大きな課題となった . 酸性雨による 腐食が, 文化財などで問題化したが， 一般の構造物ではあまり顕在化しな かったのは幸いであった .

1995 年に発生した阪神淡路大震 災による山陽新幹線などの構造物の 損傷によって，コンクリート構造物 の原料や工事の不適正がもたらす危 険性が改めて明らかとなった . 鉄筋 の腐食が進んでいたが，これは鉄筋 自体の問題ではなく，より適正な原 料・施工による解決の重要性が強く 認識された .

2000 年代になると, 高齢化が進 む社会において, 循環型社会の構築 が重要な課題となった. 要求される のは, 材料・構造物の長寿命化と再 利用である．腐食防食の立場からは， 長寿命化は以前から進められていた が , 再利用の面では今のところ顕著 な研究開発実績はない .

腐食防食は多樣化の時代であり，ある種の研究開発へ の重点化は見られない .

2009 年度末からの供用を目標に, 羽田空港第 4 滑走路 が海上に建設されるが, 栈橋構造となる部分の 100 年の 腐食に対する耐久性と低メンテナンス化は, 前世紀の技 術の進歩の総決算と言える。

\section{3. 鋼構造物防食の進歩}

\section{1 耐候性鋼の開発と利用2),3)}

有効成分として, 銅, クロム, ニッケルなどを添加し た低合金耐食鋼である耐候性鋼は, 無塗装のまま大気中 で使用するとき，生成するさび層の腐食保護性のため， さび層安定化後の腐食が小さいという特性を持つ．もと もと米国で 1933 年に開発され, 貨車, 客車 , トラック, 農業用機械, 産業用機械などの塗装メンテナンス軽減の ために塗装して使用されていた .

米国で建築物への無塗装使用が始まった 1960 年代， 日本でも耐候性鋼が開発ないし技術導入され，市販され るようになった . わが国における耐候性鋼の開発と利用 の経過を，表 2 に示した .

初期には米国での動向の影響を受けて建築物への利用 が主であったが，不満足な結果に終わるケースも少なく なかった．当時の高度経済成長に付随した SOx 污染が激
80 年代後期になると, 構造物の美麗化, 住宅用材料の 性能向上が着目され, ステンレス鋼の耐さび性向上など が重要な研究対象となった .

耐久性を重視して重防食塗装系が採用され, 塗装の歴史 における新時代を開いた . 米国などでは石油供給確保の ため, 腐食性の高い, 深い油井の開発が進んだ .これに 用いる油井用の材料として, 高耐食性油井管の研究開発 盛んであった

た．上水やガスを供給する建物周辺の埋設配管の早期の 者保護のため, 自動車の融雪塩によるさび発生や穴あき に対する防錆基準が，カナダ，米国，北欧などで作成さ 1981 年, 米国の社会資本構造物の劣化の状況を述べた 子の作用によるコンクリート橋梁の鉄筋の腐食が多数発 要な課題として着目され, 調査や対策が検討され実施さ れた 
表 2 耐候性鋼の利用

\begin{tabular}{|c|c|c|c|}
\hline 西暦 & 全般 & 建築物への利用 & 橋梁への利用 \\
\hline $1955 \sim$ & \begin{tabular}{|l} 
耐候性鋼開発 \\
大気污染激化 \\
\end{tabular} & & \\
\hline 1965〜 & $\begin{array}{l}\text { 石 油 危 機 } \\
(' 73)\end{array}$ & $\begin{array}{l}\text { ビルへの利用主体 } \\
\text { さび安定化不良の例 } \\
\text { かなり }\end{array}$ & 鉄鋼会社社内质どに例 \\
\hline $1975 \sim$ & $\begin{array}{l}\text { 低経済成長へ } \\
\text { 大気污染改善 }\end{array}$ & $\begin{array}{l}\text { 利用ほとんどなくな } \\
\text { る }\end{array}$ & $\begin{array}{l}\text { 道路橋への利用開始（'78） } \\
\text { 適用可能地域決定への共研（'82～) } \\
\text { 道路橋への利用急增（'82 年） }\end{array}$ \\
\hline 1985 & & & $\begin{array}{l}\text { 道路橋への利用年間 } 100 \text { 橋以上（'87） } \\
\text { 道路橋への利用累積約 } 1000 \text { 橋 ('91) } \\
\text { 適用可能地域決定 ('93) }\end{array}$ \\
\hline $1995 \sim$ & $\begin{array}{l}\mathrm{Ni} \text { 系 (海岸 } \\
\text { 用) 耐候性鋼 } \\
\text { 開発 }\end{array}$ & & $\begin{array}{l}\text { 道路橋への利用累積約 } 4000 \text { 橋（'02） } \\
\mathrm{Ni} \text { 系而䐅性鋼利用累積約 } 62 \text { 橋（'02） }\end{array}$ \\
\hline
\end{tabular}

しい地域や，もともと使用が不適当な海塩粒子付着が過 度の臨海地域でのさび層安定化不良, さび層が安定化す る数年ないし 10 年近い期間におけるさび層のむらなど 外観上の問題，さび表面を伝わった鉄イオンを含む雨水 (いわゆる「さび汁」）による下辺のコンクリートなどの 污損が主な理由である.さびむら解消のため構造物の形 状的工夫が行われ，大気污染も次第に改善されたが， 1980 年頃までに建築物における耐候性鋼の利用は，ほと んどなくなった .さび層安定化への不信と同時に，建築 物においては塗装しないことの経済効果は大きくないこ と，無塗装耐候性鋼の外観がデザイン効果を与える建築 物は限られることなども影響した 。

橋梁への耐候性鋼の無塗装使用は 70 年代までは試行 的な数例に限られていた。しかし, 第一次石油危機から 約 10 年経過した 1980 年代前半になると, 莫大な費用を 要する橋梁の塗装の塗替えが大きな経済的負担となり， 道路橋を中心に光の利用が始まり，急速に増加して行っ た . 橋長 30 メートル以上の無塗装耐候性鋼橋梁の累積 数は, 1990 年代初めまでに約 1000 橋 2002 年度までには約 4000 橋に達した2)。 耐候性鋼は石油危機によって赤ったので ある 。

橋梁への利用においても，さび層安定 化を有利にするため, 滞水, 漏水, 雨水 の定常的水みち形成の回避などの設計的 改善が進められた．また，建設省土木研 究所 $\left(\right.$ 当時 $\left.{ }^{*}\right)$ は鋼材俱楽部 (当時**) , 及び日本橋梁建設協会と共同で, 全国 41 力所の既存の道路橋に試験片を取り付け て 9 年間の暴露試験を行い, さび層安定 化の調査結果に基づいて, 1993 年 , 海塩 粒子付着量が限度を超えず，無塗装耐候 性鋼の適用が可能な地域を決定した ${ }^{4)}$ 。 現在では，耐候性鋼は橋梁建設用材料と して，定位置を確保している。

一方，適用可能地域外となる臨海地域

* 現在, 独立行政法人 土木研究所.

**2001 年, 日本鉄鋼連盟に統合.
での橋梁建設数は多いので, 臨海地域でもさび層が安定 化して产の適用が可能であるニッケル系高耐候性鋼が乥 の後研究開発され，2002 年までに約 60 橋での使用実績 ができた

\section{2 パイプランの電気防食}

パイプラインの電気防食技術は, 天然ガスパイプライ ンの発展につれて米国において 1935 年頃からしだいに 普及した . 1945 年頃までに一応の技術的確立を見たが， 弚の後の幹線の延長拡大とともに発展して行った。

わが国における初期の経過を，表 3 に示す.最初の長 大パイプラインは，1962 年に完成した新潟 - 東京天然ガ スパイプライン $(335 \mathrm{~km})$ であり, 電気防食の本格的適 用もこの時である.塗覆装はアスファルト/ ガラスクロス で, 外部電源法と選択排流法が用いられた 。

1960 年代後半, 首都圈や近畿地区でいくつかの都市ガ ス幹線が建設され，以前から開発されていたポリエチレ ン被覆鋼管の使用が定着した . 1971 年, 日本最初の長大

表 3 初期におけるわが国のパイプライン電気防食の発展

\begin{tabular}{|c|c|c|}
\hline 西暦 & 米国 & 日本 \\
\hline $1935 \sim$ & $\begin{array}{l}\text { 天然ガスパイプラインの発展 } \\
\text { 電気防食, 次第に普及 }\end{array}$ & \\
\hline $\begin{array}{l}\text { 1945 } \\
\text { (終戦) }\end{array}$ & $\begin{array}{l}\text { 電気防食技術, 一応磪立 } \\
\text { NACE 設立 } \\
\text { ‘45～幹線発展, 電気防食発展 }\end{array}$ & 1949 東京電蝕防止対策涹員会設立 \\
\hline 1955〜 & 幹線 142,000 マイルに & $\begin{array}{l}\text { 1956〜ポリエチレン被覆鋼管普及へ } \\
1962 \text { 新 潟〜東 京 天 然ガ ス PL } \\
\text { (335km) (アスファルト/ガラスクロ } \\
\text { ス被覆, 選択排流・外部電源法) }\end{array}$ \\
\hline 1965 & $\begin{array}{l}\text { Peabody : “Control of Pipe- } \\
\text { line Corrosion" (NACE '65) } \\
\text { SCC 問題発生 } \\
\text { NACE 電気防食基準（RP-01- } \\
69 \text { ) } \\
\text { 政府パイプライン安全基準 } \\
\text { (OPS '71) }\end{array}$ & $\begin{array}{l}\text { 1968〜首都圈, 近畿地区に諸ガス幹 } \\
\text { 線（ポリエチレン被覆鋼管使用） } \\
\text { 電防技術の進歩へ(含：測定技術) }\end{array}$ \\
\hline 1970 代 & & 1971 東京湾横断海底幹線 $(26 \mathrm{~km})$ \\
\hline
\end{tabular}


海底管である東京湾横断海底ガス幹線 $(26 \mathrm{~km})$ が敷設さ れた.

電気防食施工技術は当然進歩したが，見逃せないのは， 必要防食電流の決定方法, 測定される電位の解釈などの 進歩を含め, 施工，管理に必要な測定技術が確立された ことである. 69 年に制定された米国の電気防食技術の結 集である “Control of External Corrosion on Underground or Submerged M etallic Piping Systems" (NACE Standard RP-01-69（1969）；1992 年版が最新）は，大きな助けとな った .

今日までに重要な埋設パイプラインが増加し，電気防 食技術は世界最高水準にある . わが国の首都圏など直流 電鉄網が広がっている地域の埋設パイプラインでは, 米 国などに比べて迷走電流による腐食（いわゆる「電食」） 対策がはるかに重要であり, 排流法や定常的な電気防食 だけでは対応できず, 自動電位調節など, 独自の技術が 大きく発展したという特色がある．

電食防止のために関係者の連絡協調を密にし, 必要な 各種の調査及び測定などを行い，これらの対策を研究し， かつ実施の促進を図るため, 電鉄, ガス，水道，電力， 電気通信などの業者に学識経験者を加えた電食防止対策 のための委員会がある.1949年に設立された東京電蝕防 止対策委員会を最初として，わが国 5 地域で活動を続け ている．例えば東京電蝕防止対策委員会の場合, 会員か らの提案による具体的調査の件数は, 毎年 80〜100 件に 上る.

種々の分野における防食技術の中で，埋設パイプライ ンの光れは最も整備され有効なものと言える．

3.3 鉄筋コンクリート構造物の鉄筋の塩害対策 鉄筋コンクリート構造物（RC 構造物）の鉄筋の塩害対 策の経緯を，表 4 に示した .

1950 年代後半から, わが国で RC 構造物の建造が急増
したため，細骨材として使用する川砂不足の傾向を生じ， 一部に海砂の使用が始まった . 海砂の洗浄が悪く，塩化 物が多く付着していると鉄筋を腐食させるため, 日本建 築学会では最初の塩化物限度量をこの頃規定している5 ${ }^{5}$.

1960 年代に入ると，高度経済成長に伴って RC 構造物 の建設はさらに増加し，川砂不足は深刻となり，60 年代 後半以降, 洗浄不良の海砂使用が多くなった . また, 工 場で調配合するフレッシュコンクリート（生コン）が広 く使用されるようになり, 大きな水/コンクリート比 （W/C 比），高い塩化物量，アルカリ反応性骨材の使用な ど，品質の悪い生コンが使用されるケースが増大した . 同時に，施工の不良も多発するようになった .

1980 年代になると光の影響が顕在化し，コンクリート の割れ・はがれ，鉄筋の腐食，アルカリ骨材反応などの 発生が, 多数の既設構造物で問題となった ${ }^{6)}$. 山陽新幹 線の橋脚や床版に生じた損傷が兴の典型例である . 生コ ンの品質を確保するため, 日本建築学会7) やJIS ${ }^{8)}$ では, 生コン中の塩化物イオンの量を $0.30 \mathrm{~kg} / \mathrm{m}^{3}$ 以下と定める と共に, アルカリ骨材反応防止のための基準を作成した . この結果, 生コンの品質, ひいては新規のコンクリート 構造物は大きく改善された. しかし, 過去の不良構造物 は蓄積されており, 光の弱点は, 1995 年に発生した阪神 淡路大震災によって, 世間の注目を広く集めることとな った .

一方, 80 年代, 臨海地域では, RC 橋表面に付着した 飛来塩分が内部に浸透して鉄筋を腐食させるという事例 が多数見い出され，新しい問題として浮上した ${ }^{9)}$. 建築 物でも同じ問題を生じた ${ }^{10)}$ 。この対策として臨海 RC 構 造物では, W/C 比の低減, 表面の被覆など, 塩化物イオ ンの浸透を抑制する方法か採用されるようになった ${ }^{10)}$.

品質の良い生コンを用いて正しく施工された健全な $\mathrm{RC}$ 構造物では, 外来の塩分などの影響がない場合, 光 の耐久性は空気中の二酸化炭素の作用で外部からゆっく

表 4 鉄筋コンクリート $(\mathrm{RC})$ 構造物の劣化への対応

\begin{tabular}{|c|c|c|c|}
\hline 西暦 & 社会の動き & コンクリート事情 & 対策など \\
\hline 1955 & $\mathrm{RC}$ 構造物建設急増 & $\begin{array}{l}\text { 川砂不足の傾向 } \\
\text { 海砂使用へ('57〜) }\end{array}$ & $\begin{array}{l}\text { 細骨材中 } \mathrm{NaCl} \leqq 0.01 \% \text { を規定 } \\
\text { (日本建築学会) }\end{array}$ \\
\hline $1960 \sim$ & $\begin{array}{l}\text { 高度経済成長へ } \\
\text { 首都高速道路, 東海道 } \\
\text { 新幹線, オリンピック } \\
\text { 施設建設 }\end{array}$ & 川砂不足深刻化（'63～) & \\
\hline 1965 & $\begin{array}{l}\text { フレッシュコンクリー } \\
\text { ト(生コン) 使用へ } \\
\text { 阪神高速道路, 山陽新 } \\
\text { 幹線建設 }\end{array}$ & $\begin{array}{l}\text { 洗浄不良海砂使用増大 } \\
\text { 生コン品質低下（W/C } \\
\text { 比大. 塩化物大, アルカ } \\
\text { リ反応性骨材使用） }\end{array}$ & \\
\hline $1980 \sim$ & $\begin{array}{l}\text { 沿岸 } \mathrm{RC} \text { 橋梁塩害問題 } \\
\text { 発生（飛来塩分の影 } \\
\text { 響, } 82 \text { ) }\end{array}$ & $\begin{array}{l}\text { 割れ, 剥が狆, 鉄筋腐食 } \\
\text { 増大, アルカリ骨材反応 } \\
\text { 発生 (建築物, 橋梁など) }\end{array}$ & $\begin{array}{l}\text { JIS A 5308-86, JASS } 5-1986 \\
\text { 生コン中 } \mathrm{Cl}^{-} \leqq 0.30 \mathrm{~kg} / \mathrm{m}^{3} \\
\text { アルカリ骨材反応防止策 } \\
\text { 生コン品質改善へ }\left(\mathrm{Cl}^{-} \text {, 反応 }\right. \\
\text { 性骨材 })\end{array}$ \\
\hline 1990 & 阪神淡路大震災 & $\begin{array}{l}\text { 大震災で不良 RC 構造物 } \\
\text { 弱点に一般の注目集まる } \\
\text { 品質・施工不良 RC 構造 } \\
\text { 物滅少へ }\end{array}$ & $\begin{array}{l}\text { コンクリ-上品質 管理 指針 } \\
\text { (例 : 日本建築学会 '91) } \\
\text { RC造建築物耐久性調查·骖断・ } \\
\text { 補修指針 (日本建築学会 '97) } \\
\text { 耐久設計基準強度規定 (日本建 } \\
\text { 築学会 : JASS 5-1997) }\end{array}$ \\
\hline
\end{tabular}


り進む中性化が鉄筋位置に到達して，腐食損傷を生じさ せるまでの期間によって決まる.中性化進行速度が基本 的には W/C 比の值，ひいてはコンクリートの強度によ ることから，日本建築学会では，建築物に求められる耐 用期間に応じて必要な「耐久設計基準強度」を規定し $た^{11)}$.これは，腐食がからむ構造物の耐久設計を定量的 に規定するという，他に類を見ないものとして注目され る。

\section{4 高力ボルトの遅れ破壊}

1965 年頃, 橋梁や建物て部材の摩擦接合に用いる高力 ボルトのうち, 当時のJIS 規格で引張強さ (TS) が最大 の製品であった F13T (TS : 約 $\left.130 \mathrm{kgf} / \mathrm{mm}^{2}\right)$ に遅れ破壊 が頻発した .このため, 1970 年のJIS の改定でこれを廃 止し, 引張強さが約 $110 \mathrm{kgf} / \mathrm{mm}^{2}$ の F11T までとしたが, やはり遅れ破壊の事例を生じた .このため現在では， F10T (TS : 約 $100 \mathrm{kgf} / \mathrm{mm}^{2}$ ) が一般に使用されている.

高力ボルトの強度が低いことは, ボルトの数が増え， 重量が増すなど，設計上不利である．本稿での対象外で あるが，このことは，粗製プロパンガス貯蔵用タンク， 液体アンモニア貯蔵用タンクなどに使われた高い強度の 高張力鋼材が応力腐食割れを起こしたため, 弚の後はよ り強度の低い高張力鋼材を使用していることと類似して いる。

高力ボルトにおけるこの問題に対処するため, 最近に なってようやく，遅れ破壞に強いF13T 相当又は光れ以 上の強度を持つ高力ボルトの開発が進み，耐遅れ破壊性 を実証するための努力が続けられている12).

\section{5 溶接部の腐食に対する鋼中の硫化物の影響}

現在では標準的な製品となっている連続鋳造法による 鋼材（連鋳鋼）の製造が始まった 1968 年, 関係者を驚か せたのは, 連鋳鋼は特に溶接部などにおいて海水などに よる腐食を受けやすいという，スウェーデンの学者の報 告であった .これは砕水船の外板に使用した連鋳鋼の溶 接部の腐食事例に基づくもので, 連鋳鋼では製造過程の 冷却速度が大きいため, 鋼中のいおうは安定な MnS ば かりでなく，多量の FeS となることが原因とされた。

このことは, 本稿の筆者を含む社内の WG の研究によ

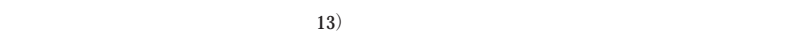
また驚いたことには，問題を提起した学者自身が 1971 年の発表論文 ${ }^{14)}$ で，砕水船の腐食を生じた鋼板は，連鋳 鋼ではなかったと述べている。

硫化物が関連する腐食が再び問題となったのは, 電縫 鋼管の電縫溶接部の急速な腐食（み状腐食）である ${ }^{3)}$. この種の腐食は海水, 工業用水, 給湯などの配管に用い られた電縫鋼管で 1965 年頃から多発し，侵食度がきわ めて大きい事例が目立った .

み光状腐食の原因は電縫溶接部が溶接後急速に冷却さ れるため，不安定な M nS を生じることにあるとされ ${ }^{15)}$ ， 1980 年代初めまでに，このような硫化物の生成を抑制す るなどした耐み攵状腐食鋼管が, 鉄鋼数社で開発され市 販された，弚の後，この種の腐食問題は生じていない．

連鋳鋼にかかわる腐食として行われた硫化物の影響に 関する研究は, 腐食したのが連鋳鋼でないことが判明し て結果的に不要であったことになるが，後日，み光状腐
食対策の研究に大いに役立った 。

\section{6 埋設管の腐食対策 ${ }^{16)}$}

わが国の腐食防食の歴史上，事例が圧倒的に多かった のは, ガスや水道を供給するための建物周辺の土壤埋設 鋼管の外面からの急速な腐食である .この種の腐食は以 前から生じていたが， RC 建物が多くなった 1960 年代か ら急増した。

光の原因は，埋設配管が建物基礎貫通部などで建物の 鉄筋と接触し, 鉄筋に対してマクロ腐食電池のアノード となることにある．パイプライン業界ではこれを避ける 措置を取ることは基本事項であったが，建物配管分野で は弚の必要性が認識されていなかった 。このため, 腐食 発生に関連して鉄筋との絶縁の必要性が指摘されても容 易に実施されず，本誌に掲載された解説「配管の土壤腐 食」(1976) ${ }^{17)} も ，$ 注目はされたものの，一部の業者を除 くと施工の改善は進まなかった .

1980 年代初め, ある小学校で埋設 LP ガス配管の不等 沈下・折損による大量のガス漏洩事故を生じた . 幸い人 身事故には至らなかったが, 調査の際, 配管の腐食が激 しいことが重大問題として注目され，国会でも問題とな つた .これを契機として行われた全国の学校, 病院, 公 会堂などの LP ガス配管の漏洩歴の調査で, 腐食貫通に よる事例が多いことが判明し, 事態は深刻に受けとめら れた。

これに対応して，腐食防止のための基準ないしガイド ラインが，高圧 LP ガス（1982），都市ガス（1985），簡易 ガス（1990）について关れ光れ作成された．この結果， 対策の重要性と光のための施工技術が広く普及し, 腐食 事故は激減した . 本件はある事故をきっかけに，長年の 懸案が比較的短期間に解決した代表的な例である。

\section{7 橋梁の長期防食}

低経済成長，老齢化などの日本社会の動向によって， 社会資本構造物の長寿命化が不可欠であることが 80 年 代から認識されるようになった，従来の橋梁では寿命を 50 年としてきたが, 仮に現存する多数の道路橋をすべて 50 年で更新するとすれば，近い将来，毎年の更新橋梁数 は極めて多くなり，低経済成長，老齡化社会では負担し きれなくなる．乥こで，橋梁は 100 年以上の耐用とする 必要を生じた。

メンテナンスが十分であれば，橋梁は 100 年以上使用 できる，有名な英国のアイアンブリッジは 1779 年の建 設以来, 200 年をはるかに超えている.ニューヨークの ブルックリン橋も 120 余年の使用に耐えている . わが国 でも 1912 年に建設された山陰線の余部鉄橋は主柱以外 の部材は取り替えたが，まもなく 100 年を迎える .

必要なメンテナンスのうち, 防食のための塗装の塗替 えは大きな項目である．しかし，橋梁の塗替えには关の 都度, 上部工建設費の $10 \%$ 程度の費用を必要とする . 海 上の長大橋ではさらに大きい .

本州四国連絡橋（本四橋）は, 設計寿命を 100 年とし た最初の橋梁である.瀬戶大橋 (1988 年完工) から明石 海峡大橋（1998 年完工）をもって全ルートが完成したが， 兴の塗替えの費用は莫大であるとともに，例えば 10 年 ごとに塗り替えるとなると 100 人以上の塗装技能者を常 
時張付けにしなければならず, 高齢化, 3K 忌避の社会 では技能者の確保が難しくなる．

メンテナンス塗装をミニマムにするために, 本四橋で は, 耐久性に優れた重防食塗装系の仕樣が, 実地試験を 含め 20 年近い検討を経て作成された . 光の後建設され た海上長大橋はすべて, 基本的には同樣の重防食塗装系 が採用されている。

本四橋に端を発した 100 年耐用の考え方は，住宅の一 部にも始まっており, 海上に建設される羽田空港第 4 滑 走路でも同樣である (3.8 節参照).

\section{8 海水飛沫帯の防食}

海に囲まれ，海洋立国であるわが国では港湾施設は重 要であるが, 海水飛沫帯の腐食が激しいことはよく知ら れている.1960 年代, 第 2 の耐候性鋼を意図して, 主と して海水飛沫帯の耐食性に優れた低合金組成の耐海水鋼 の開発が進められた ${ }^{3}$.また，この特性を持つ耐食鋼が 米国ではすでに開発されていたため, 弚の技術導入も行 われた .

耐海水鋼の開発における一つの課題は，溶接部での腐 食を防ぐための溶接金属の成分系の決定, 及び溶接熱影 響部での腐食を抑制するための母材の成分系の決定であ った．海水環境などでは普通鋼でも溶接部が腐食する傾 向にあり, 基本的にはSi や M n の量の適正化によって軽 減するとされるものの系統的な研究はほとんどないの は，20世紀の積残しである. 耐海水鋼は無塗装で使うた め溶接部の腐食対策が不可欠であるのに対し，普通鋼で は被覆などの防食手段が施されることが, 溶接部の腐食 問題への関心を低くさせているのであろう .

耐海水鋼の開発は 1970 年代初期にはほぼ完了し数社 から市販されたが，ほとんど採用されるに至らなかった． 当時護岸などで防食措置があまり採られなかったこと， 飛沫帯での耐食性が普通鋼の約 2 倍という性能がアピー ルしなかったことなどが原因であろう . 後者の理由は， 低合金耐食鋼は廉価ながら，光の限られた特性が時代の ニーズに適合しなければ成功しないという宿命をよく現 している.成功した耐候性鋼も，市販開始から 20 余年 を経て，塗替えの費用が経済を圧迫するという， 3.1 節 で述べた状況が生じなかったならば，広く受け入れられ なかったであろう．

さて, わが国では船混み問題解消のため 1960 頃から 港湾施設の整備が大いに進んだが, 防食措置への関心が 低かったため, 1980 年代には改修が必要な施設が目立ち 始めた . なかでも護岸の腐食は大きな問題であった .

この事態を予測して，1970 年代前半，鉄鋼会社の一部 では種々の防食被覆を施した鋼杭の大規模な海洋暴露試 験を開始し ${ }^{*}$, 後半になると建設省土木研究所 (現在, 独 立行政法人），(財)沿岸開発技術研究センター，(財) 国 土技術研究センター, 鋼管杭協会, 鋼材俱楽部（前出） などがいくつかの組合せの組織によって, 波崎沖, 千葉 沖, 阿字ヶ浦沖ほかの試験所で, 試作防食杭の実地試験 を開始した ${ }^{18)}$.

1980 年代前半には, ポリエチレンやポリウレタンを被

* 代表例として,NKK（現JFE スチール）が福山製鉄所（当時）の海岸 で実施したものが知られている
覆した鋼管杭, 鋼管矢板, 鋼矢板を初め, ペトロラタム テープと FRP のコンポジットライニング工法などが広く 実用されるようになり，これが定着して，わが国の海洋 環境での防食は画期的に進歩した．1990年代になって， 先に述べた設計寿命 100 年への動向に合わせた新しい防 食方法が出現した．すなわち，1994 年に完成した関西国 際空港連絡橋及び 1997 年に完成した東京湾横断道路の 橋脚の海水飛沫帯では, 弚れ光れ, 鉄筋コンクリート $500 \mathrm{~mm}$ + 鋼板 $28 \mathrm{~mm}+$ エポキシ樹脂系塗装 $2.5 \mathrm{~mm}$ のラ イニング , $1 \mathrm{~mm}$ 厚のチタンクラッド鋼板ライニングと いう長期に耐える防食被覆を使用している.

2009 年度末からの供用が予定されている羽田の東京国 際空港 D 滑走路は海上にあり, 埋立部に続く $1100 \mathrm{~m}$ が ジャケットによる栈橋構造である. 100 年の設計耐用年 数に対応して, 兴の飛沫・干満帯には耐海水ステンレス 鋼ライニングを使用すると共に, 大規模な点検・補修を 計画している .

\section{9 『荒廃するアメリカ』の教訓}

1981 年米国で出版され翌年わが国でも翻訳された著書 『荒廃するアメリカ』 ${ }^{19)}$ は, 1970 年代までに大いに整備が 進んだわが国の社会資本構造物の劣化対策，ひいては腐 食対策の進歩に大きなインパクトを与えた . 1950 年代に ゴールデンエージを享受した米国社会は, 1965 年頃から の緊縮予算とインフレによって公共事業投資額が減少 し, 社会資本ストックの補修, 維持管理が十分行われな くなった結果, これらの老朽化が進んだが, 光の状況が 同書に示されている.この再生のためには, 弚の後の 20 年間に 1 兆ドルとも 3 兆ドルともいわれる投資が必要で あるとされた .

鋼材俱楽部（前出）の防せい特別委員会では，1987 年 から 2 年間に社会資本構造物の腐食・防食をテーマに数 回の防食技術セミナー20) を開催し, わが国における社会 資本構造物の腐食による劣化状況と防食技術についての 報告や討議を行ったが, 折からわが国でも港湾施設, 橋 梁, 水道などで腐食が問題になってきたため, 大きな関 心を喚起した。

1991 年, 腐食防食協会は資源協会と共催して「社会資 本の荒廃と光の対応」をテーマに公開講座を開催したが， このテーマは 1993 年に発足する本協会の腐食センター への大きな動機づけの一つであった .

こうして，「荒廃するアメリカ」という前較は，わが 国の社会資本構造物を中心とする防食対策の重要性への 認識を深め，対策の進展に寄与したことは確かである．

\subsection{0 構造物の美麗化}

高度経済成長時代は街を歩くとさびが目立ったが，大 気環境の改善, 塗装仕樣の高級化, アルミニウムやプラ スティックへの材料転換などによって，しだいにさびは 見かけなくなった . 乥して 1980 年代末期になるとアメ ニティへの志向が強くなり，建物や弚の他の構造物の長 期防食を兼ねた美麗化が重視されるようになった . 代表 的には，体育館などでのステンレス屋根の使用が増加し た .また, 地下街の柱などにも, ステンレス鋼巻きが多 くなった .

さびないステンレス鋼は当時の活発な研究の対象とな 
り，素材のほかに塗装ステンレス鋼が製品化され普及し た．また，ステンレス鋼よりさらにさびにくく，耐久性 の良い材料として, チタンの屋根もかなりの実績を挙げ た. 1993 年に完成した福岡ドームの屋根は, チタンを大 量に使用した代表例である .

都市部の高速道路橋においても美麗化が進められ，林 を視野から隠すために桁カバーが設置されるものか現れ たが, 当然, さびを防ぐ必要があり，アルミニウムやス テンレス鋼が使用されている .

一方, 耐久性と美麗化を兼ねて, ステンレス鋼の建築 構造部材としての使用について建築基準法の一般認定を 取得するための活動をステンレス協会が 1984 年から開 始し, 実証構造物の建設, 建設省（当時）新素材総合プ 口関連の研究などを経て, 1994 年,一般認定を取得した . 実績は徐々に増えつつあり，今後の発展が期待されてい る1).

\section{4 腐食防食の発展を振返って}

約半世紀にわたって経験した腐食防食の世界を通じ て，特に筆者の印象に残る事柄は次のように要約され る.

（1）耐候性鋼は, 石油危機で便った .

（2）埋設パイプラインは，防食管理の優等生.

（3）構造物耐久設計の定量的規程は，鉄筋コンクリ 一ト構造物に見習へ。

（4）遅れ破壊に耐える高力ボル卜開発は，20世紀へ のリベンジ

（5）構造物溶接部の耐食性向上は，20世紀の忘れ物 .

（6）埋設建物配管の早期穴あき防止法の普及の契機 はニアミス

（7）橋梁の 100 年耐用には重防食塗装系 . 200 年耐用 には何か.

（8） 100 年耐用の海上空港は, 飛沫帯長期防食メンテ ナンスの正念場 .

（9）「荒廃するアメリカ」の前轍を踏むな.
（10）構造物の長期美麗化には，経年的に美しくなる 材料と構造という考え方も必要.

\section{参 考 文 献}

1) 松島餀, BOUNDARY, 15, No.12, 3 (1999).

2) I. M atsushima, Zairyo-to-Kankyo, 53, 167 (2004).

3）松島巌，「低合金耐食鋼」（日本鉄鋼協会「叢書・鉄鋼技 術の流れ」,第 1 シリーズ第 7 巻)，地人書館 (1995)。

4）土木研究所, 鋼材俱楽部, 日本橋梁建設協会, 「耐候性 鋼の橋梁への適用に関する共同研究報告書 $(X X)$ ，無塗装 耐候性鋼橋梁の設計・施工要領」（改訂版）（1993）。

5）日本建築学会, 「建築工事標準仕樣書・同解説 鉄筋コン クリート工事」, JASS 5 (1957), 日本建築学会 (1957)

6）小林一輔，「コンクリートが危ない」, 岩波新書 616 , 岩 波書店 (1999).

7）日本建築学会, 「建築工事標準仕樣書・同解説 鉄筋コ ンクリート工事」, JASS 5 (1986)，日本建築学会 (1986)。

8) JISA 5308-86

9）池田政道，道路，p.62，(1984.2)。

10）大即信明，樫野紀元，片脇清士，小林明夫，宮川豊章， 「塩害 $(\mathrm{I}) 」$, 技報堂出版 (1986) 。

11）日本建築学会，「建築工事標準仕樣書・同解説 鉄筋コン クリート工事」, JASS 5-1997, p.132，156，日本建築学会 (1997).

12）建築研究所，物質・材料研究機構，日本鉄鋼連盟，「超 高力ボルトの性能評価法の開発」委員会最終報告書, (2005. 3).

13) N. Kaneko, T. Kawawa, I. M atsushima, Y. Ishizu and $Y$. Fukuda, Nippon Kokan Technical Report-Overseas, N o.9, 21 (1969).

14) G. Wranglen, International Congress on Localized Corrosion, Williamsburg, VA, Dec.6-10, 1971 ; Publ. "Localized Corrosion", p.462, NACE (1974)

15）加藤忠一，乙黑靖男，門智，防食技術，23，385（1974）。

16) 松島嚴, 日本材料学会, 第 226 回腐食部門委員会, (2002. 1).

17）松島餀，防食技術，25，563（1976）。

18）鋼管杭協会，「鋼管杭・鋼管矢板・鋼矢板 防食ハンドブ ック一設計・施工・維持管理」, p.4-10，鋼管杭協会 (1998).

19) P.Choate, S.Walter, “America in Ruins", (1981), 岡野行秀 監修, 古賀一成訳「荒廃するアメリカ」, 開発問題研究 所 (1982).

20）鋼材俱楽部防せい特別委員会防食技術セミナー，「社会 資本の腐食・防食」 1987.11 1989.11, テキスト合本出 版, (1994. 10)

(2006 年 4 月 13 日受理)

過去半世紀におけるわが国の社会資本構造物及び建築物の防食技術の発展を、社会の変化及び光れによ って生じたニーズと関連付けて概説した .これは現在の防食技術の歴史的背景を新世代に伝承することを 意図している．短い歴史的概説に続いて，10 項目のトピックについてより詳細に述べた . 取り上げたの は, 無塗装耐候性鋼の利用, 初期における埋設パイプラインの電気防食, 鉄筋の腐食を避けるためのコン クリートの品質管理, 高力ボルトの遅れ破壊対策, 水配管に用いる耐み光状腐食電縫鋼管の開発, 建物周 辺の埋設配管の早期腐食対策, 長大海上橋梁への重防食塗装系の適用, 海水飛沫帯防食のためのライニン グ 、『荒廃するアメリカ』(P.Choate, S. Walter 著) の衝撃的教訓，及びアメニティのための建築物外装へ の耐さび性ステンレス鋼とチタンの使用である.

キーワード 社会資本構造物, 耐候性鋼, 電気防食, パイプライン, 鉄筋コンクリート構造物, 高力 ボルト，埋設設備配管，重防食塗装系，飛沫帯ライニング 